\title{
Effect of Flyash Addition on Mechanical and Gamma Radiation Shielding Properties of Concrete
}

\author{
Kanwaldeep Singh, ${ }^{1}$ Sukhpal Singh, ${ }^{2}$ and Gurmel Singh ${ }^{1}$ \\ ${ }^{1}$ Department of Physics, Punjabi University, Patiala 147002, India \\ ${ }^{2}$ Department of Basic and Applied Sciences, Punjabi University, Patiala 147002, India \\ Correspondence should be addressed to Sukhpal Singh; sukhpal_78@rediffmail.com
}

Received 8 May 2014; Accepted 28 October 2014; Published 16 November 2014

Academic Editor: Bilal A. Akash

Copyright (c) 2014 Kanwaldeep Singh et al. This is an open access article distributed under the Creative Commons Attribution License, which permits unrestricted use, distribution, and reproduction in any medium, provided the original work is properly cited.

Six concrete mixtures were prepared with $0 \%, 20 \%, 30 \%, 40 \%, 50 \%$, and $60 \%$ of flyash replacing the cement content and having constant water to cement ratio. The testing specimens were casted and their mechanical parameters were tested experimentally in accordance with the Indian standards. Results of mechanical parameters show their improvement with age of the specimens and results of radiation parameters show no significant effect of flyash substitution on mass attenuation coefficient.

\section{Introduction}

With the increasing applications of radioactive isotopes in several fields of science and technology, there arises the need of using them with extreme care, only after having proper shielding. Efficiency and cost of the material are the two factors that are primarily taken care of, for selecting any material for field applications. Concrete is the most widely used material for shielding gamma radiations satisfying the guidelines. It is used in abundance, particularly due to its good radiation shielding and mechanical properties [1]. Concrete has structure heterogeneous in nature and the origin of its peculiar characteristics is its internal structure. The structure/microstructure variation for a material is a very important factor which plays a crucial role in determining the mechanical properties and its deformation behaviour. The knowledge of complex relation between properties of concrete ingredients and its structure assists in preparing concrete mixture according to the requirements as it has lasting effect on workability, early strength, shrinkage of hardened concrete, and permeability characteristics of concrete.

To make cost effective concrete, research has been carried out to use minimum amount of cement and aggregates and utilise by-products in as much quantity as possible. Ground blast furnace slag, silica fume, foundry sand, cement kiln dust, and flyash are the major materials that have been tested as an alternative of cement. Among the various admixtures, flyash is most suitable due to its pozzolanic nature. Not only does flyash play the role of filler but it also has the properties of a binder. It reacts with free lime liberated during the hydration of cement resulting in positive effect on late age strength of concrete. It is particularly suitable to use in mass concrete applications where the cement requirement is large.

The properties of fresh and hardened concrete have been studied in detail by various workers. Workability, slump loss, setting time, bleeding, segregation, and a number of related practical issues are addressed among the properties of fresh concrete [2-5]. Among the hardened concrete properties, compressive strength and other mechanical and physical properties of hardened concrete such as tensile strength, elastic properties, shrinkage, creep, cracking resistance, electrical and thermal transport, and other properties were studied [6-15]. Also the effects of addition of flyash in preparing concrete on the quality, workability, and durability were studied. Durability of concrete having certain amount of flyash in place of cement was superior to concrete without flyash [16-18], the effect of flyash incorporation on the water demand was reported [19-21], the compressive strength of flyash concrete showed continuous improvement with age [22-25], and early shrinkage behaviour of flyash concrete was 
studied [26, 27]. The above reported effects of flyash addition to concretes are due to suitable changes in the structure of concretes.

The interaction of gamma radiation with matter has been studied in the past by several workers in concretes with the help of different interaction parameters such as mass attenuation coefficients [28-33]. Flyash was studied as a radiation shielding material for gamma rays and reported that it if compacted to high degree it can be used for shielding [34].

In this study, concrete specimens were prepared with flyash substituting different percentages of cement. The mechanical properties, slump, compressive strength, flexural strength, and modulus of elasticity, were measured for the prepared samples. Along with these mechanical properties, the radiation interaction parameters, namely, linear and mass attenuation coefficient, were also calculated for the prepared specimens.

\section{Material and Methods}

2.1. Materials. Ordinary Portland cement (43 grade) was used. The physical properties of cement are given in Table 1 as specified by Indian specifications IS: 8112-1989 [35]. Flyash used in the study was obtained from thermal power plant, Bathinda. Flyash used was of Class $\mathrm{F}$ type $(\mathrm{CaO}<10 \%)$. Fine aggregate (natural sand) used in this study was having $4.75 \mathrm{~mm}$ maximum size. Coarse aggregate (gravel) used in this study was of $12.5 \mathrm{~mm}$ nominal size. The results of physical properties and sieve analysis are given in Table 2. Potable water was used as mixing water for preparation of specimens.

2.2. Methods. Six concrete specimens were prepared. One mixture was made without using flyash and other mixtures were made with flyash as a replacement for cement by weight. Cement was replaced with $20 \%, 30 \%, 40 \%, 50 \%$, and $60 \%$ of flyash by weight. The mixture proportion $\left(\mathrm{kg} / \mathrm{m}^{3}\right)$ of prepared concrete specimens is shown in Table 3. The concrete samples were prepared with same water to cementitious ratio. $W / c=$ 0.40 was taken for preparing samples. This ratio was taken as constant, so as to only investigate the effect of flyash addition to the ordinary concrete. The prepared samples were named as $\mathrm{OC} 1, \mathrm{OC} 2, \mathrm{OC} 3, \mathrm{OC} 4, \mathrm{OC} 5$, and OC6, in which $0 \%, 20 \%$, $30 \%, 40 \%, 50 \%$, and $60 \%$ of flyash have replaced the cement content.

The test specimens were prepared according to specifications of IS: 516-1959 [36]. Concrete cubes of $150 \mathrm{~mm}$ in size were casted for testing compressive strength of specimens. Test specimens of $100 \times 100 \times 500 \mathrm{~mm}$ beams were casted for testing flexural strength. Test specimens of $150 \times 300 \mathrm{~mm}$ cylinders were casted for testing modulus of elasticity. They were kept in casting room for 24 hours at a temperature about $25^{\circ} \mathrm{C}$. They were demolded after 24 hours and then put into water bath until the time of testing [37]. At the end of curing period, several tests were done on test specimens to determine some of their mechanical properties and the results obtained are shown in the following section.

The mass attenuation coefficients of all six concretes have been calculated with the help of winXCOM, a computer
TABLE 1: Physical properties of Portland cement.

\begin{tabular}{lc}
\hline Physical test & Requirement IS: 8112-1989 \\
\hline Fineness (retained on $90 \mu \mathrm{m}$ sieve) & $10 \mathrm{max}$. \\
Time of setting (min.) & $30 \mathrm{~min}$. \\
Initial & $600 \mathrm{max}$. \\
Final & \\
Compressive strength $(\mathrm{MPa})$ & $33 \mathrm{~min}$. \\
28 days & $43 \mathrm{max}$. \\
91 days & 3.15 \\
Specific gravity & \\
\hline
\end{tabular}

program initially developed by Berger and Hubbell and later modified to window version by Gerward et al. [35].

\section{Theory}

Workability of fresh concrete is defined by two parameters, homogeneity and consistency. Homogeneity was checked by the uniform distribution of constituents and consistency was checked by slump cone test.

Compressive strength is the capacity of concrete to withstand axially directed pushing forces. It is a measure of force that can be applied to the concrete before it cracks or fails. The flexural strength estimates the load under which the cracking will develop. The modulus of elasticity, also known as secant modulus, is calculated for $33 \%$ of the maximum stress. It reflects the ability of the concrete to deform elastically.

When a beam of monochromatic radiations passes through matter, the intensity of the beam is reduced to some extent. The decrease in intensity of radiation from $I_{o}$ to $I$ is given by Lambert-Beer law:

$$
I=I_{o} e^{-(\mu / \rho) \rho x},
$$

where $\rho$ is density of target sample, $x$ is the thickness of target sample, and $\mu / \rho\left(\mathrm{cm}^{2} / \mathrm{gm}\right)$ is mass attenuation coefficient, denoted by $\mu_{\rho}$. For a compound or mixture, it is given by

$$
\frac{\mu}{\rho}=\sum w_{i}\left(\frac{\mu}{\rho}\right)_{i},
$$

where $w_{i}$ and $(\mu / \rho)_{i}$ are the weight fraction and mass attenuation coefficient, respectively, of the constituent element $i$. The linear attenuation coefficient, $\mu\left(\mathrm{cm}^{-1}\right)$, was calculated by multiplying $\mu_{\rho}$ by the density of samples.

\section{Results and Discussion}

\subsection{Mechanical Parameters}

4.1.1. Workability. Slump was measured as per IS: 1199-1959 [38] by slump cone test having top diameter $10 \mathrm{~cm}$, bottom diameter $20 \mathrm{~cm}$, and height $30 \mathrm{~cm}$. The measured slump of control specimen was $76 \mathrm{~mm}$. Plastic concrete with the slump around this true value can fill the mold properly with good concrete quality. 
TABLE 2: Sieve analysis of aggregates.

\begin{tabular}{|c|c|c|c|c|c|}
\hline \multicolumn{2}{|c|}{ Fine aggregates } & \multirow{2}{*}{$\begin{array}{l}\text { Requirement } \\
\text { IS: } 383-1970\end{array}$} & \multicolumn{2}{|c|}{ Coarse aggregates } & \multirow{2}{*}{$\begin{array}{l}\text { Requirement } \\
\text { IS: 383-1970 }\end{array}$} \\
\hline Sieve size & $\begin{array}{l}\text { Percent } \\
\text { passing }\end{array}$ & & Sieve size & $\begin{array}{l}\text { Percent } \\
\text { passing }\end{array}$ & \\
\hline $4.75 \mathrm{~mm}$ & 97 & $90-100$ & $12.5 \mathrm{~mm}$ & 96 & $95-100$ \\
\hline $2.36 \mathrm{~mm}$ & 92 & $85-100$ & $10 \mathrm{~mm}$ & 73 & $40-85$ \\
\hline $1.18 \mathrm{~mm}$ & 78 & $75-100$ & $4.75 \mathrm{~mm}$ & 5 & $0-10$ \\
\hline $600 \mu \mathrm{m}$ & 63 & $60-79$ & & & \\
\hline $300 \mu \mathrm{m}$ & 37 & $12-40$ & & & \\
\hline $150 \mu \mathrm{m}$ & 4 & $0-10$ & & & \\
\hline
\end{tabular}

TABLE 3: Mixture proportions $\left(\mathrm{kg} / \mathrm{m}^{3}\right)$.

\begin{tabular}{lccccccc}
\hline Sample & Cement & \multicolumn{2}{c}{$\begin{array}{c}\text { Flyash } \\
\text { Weight }\end{array}$} & Water & w/(c+fa) & $\begin{array}{c}\text { Fine } \\
\text { aggregate }\end{array}$ \\
\hline OC1 & 484 & 0 & 0 & 194 & 0.4 & 638 & 638 \\
OC2 & 387 & 20 & 97 & 194 & 0.4 & 638 & 1078 \\
OC3 & 339 & 30 & 145 & 194 & 0.4 & 638 \\
OC4 & 290 & 40 & 194 & 194 & 0.4 & 638 \\
OC5 & 242 & 50 & 242 & 194 & 0.4 & 1078 \\
OC6 & 294 & 60 & 290 & 194 & 0.4 & 638 \\
\hline
\end{tabular}

4.1.2. Compressive Strength. After measuring the gamma ray interaction parameters, the samples were then checked out for its mechanical strength. It is clear from Figures 1(a) and (b) that the early age strength of flyash concrete is less than the anticipated value and it goes on increasing with the passage of time. We can also conclude that the continuous strength gain of flyash concrete increases more with the elapsing of time than for ordinary concrete without flyash.

The effect of flyash addition to ordinary concretes for all the six specimens on the compressive strength of specimens with age of 7,28 , and 91 days by compression testing machine is shown in Figure 2. The compressive strength of concrete at a given age under given curing conditions depends mainly on water to cementitious ratio and varies in accordance with Abram's law [39] defining the relation between compressive strength and $w / c$ ratio. Figure 2 shows that the compressive strength of prepared specimens decreases with the addition of flyash in place of cement and it decreases with the increase in flyash content. This conclusion is true for any number of days of testing. The compressive strength of OC1 concretes decreased by $75 \%$ after 7 days, 59\% after 28 days, and $56 \%$ after 91 days with flyash replacing cement by $60 \%$. Also the reduction in compressive strength is enhanced by $143 \%$ after 28 days and $183 \%$ after 91 days for concrete having $60 \%$ flyash in place of cement instead of increase of $46 \%$ after 28 days and by $59 \%$ after 91 days for ordinary concrete. The compressive strength results show that flyash concrete mixtures can be used for structural purposes, although lower compressive strength results for flyash concretes are obtained as the strength will increase with age.

4.1.3. Flexural Strength. The flexural strength of the prepared samples was determined at the age of 7,28 , and 91 days. The results of the flexural strength variation for the replacement of cement with five different percentages of flyash with age are shown in Figure 3 and it clearly showed that the strength increased with number of days. As is clear from Figure 3, it decreased with an increase in flyash content in place of cement and it decreased by $50 \%$ after 7 days, $36 \%$ after 28 days, and $34 \%$ after 91 days for concrete containing $60 \%$ flyash in place of cement. Also the reduction in flexural strength is enhanced by $56 \%$ after 28 days and $67 \%$ after 91 days for concrete having $60 \%$ flyash in place of cement instead of increase of $21 \%$ after 28 days and by $26 \%$ after 91 days for ordinary concrete. As expected, the flexural strength of concrete is relatively low in comparison to the compressive strength. As the compressive strength of concrete increases with age, the flexural strength also increased but at a decreased rate.

4.1.4. Modulus of Elasticity. It was determined for all the samples at the age of 7,28, and 91 days. Figure 4 shows the elastic modulus development with time for the concrete specimens containing different percentages of flyash. The variation of modulus of elasticity with change in flyash content is similar to the variation of tensile strength. Figure 4 indicates that the modulus of elasticity reduced by $50 \%$ after 7 days, $36 \%$ after 28 days, and $34 \%$ after 91 days for concrete having $60 \%$ flyash in place of cement. Figure 4 clearly shows that the modulus of elasticity of concrete specimens increased with age of concrete. The reduction in elasticity modulus is enhanced by $56 \%$ after 28 days and $68 \%$ after 91 days for concrete having $60 \%$ flyash in place of cement instead of increase of $21 \%$ after 28 days and by $26 \%$ after 91 days for ordinary concrete.

\subsection{Radiation Parameters}

4.2.1. Attenuation Coefficient. The elemental composition of the six concretes used in this study is shown in Table 4 


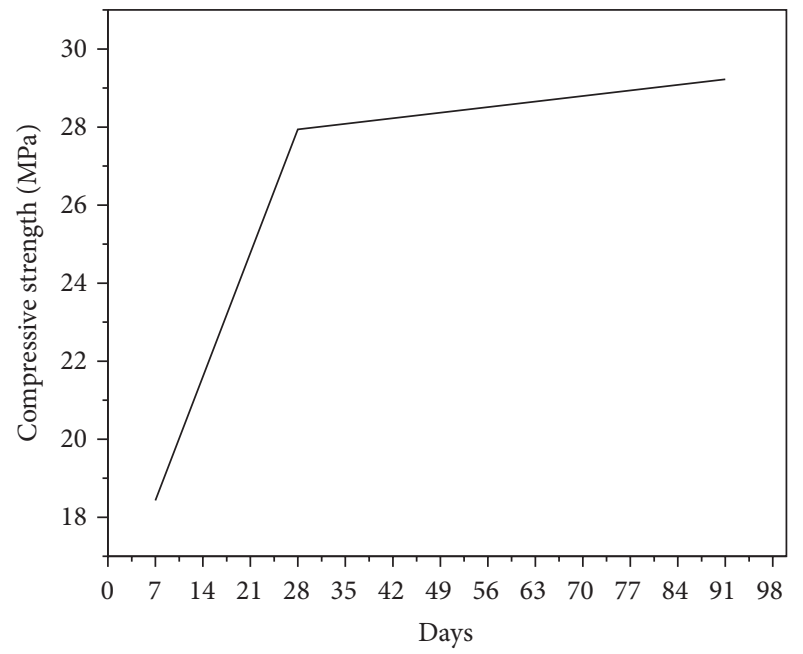

(a)

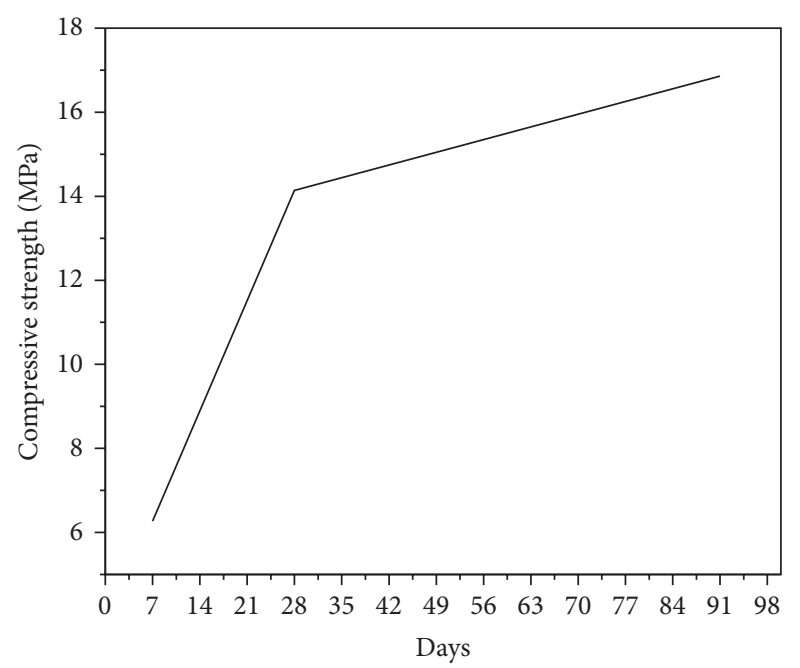

(b)

FIGURE 1: (a) Compressive strength of ordinary concrete versus age. (b) Compressive strength of flyash concrete versus age.

TABLE 4: Elemental analysis of concrete mixtures.

\begin{tabular}{|c|c|c|c|c|c|c|}
\hline \multirow{2}{*}{ Element } & \multicolumn{6}{|c|}{ Weight fraction } \\
\hline & $\mathrm{OC} 1$ & OC2 & OC3 & $\mathrm{OC} 4$ & OC5 & OC6 \\
\hline Carbon & 0.05717 & 0.05460 & 0.05330 & 0.05200 & 0.05080 & 0.04916 \\
\hline Oxygen & 0.48899 & 0.49163 & 0.49284 & 0.49404 & 0.49524 & 0.49412 \\
\hline Sodium & 0.00300 & 0.00301 & 0.00301 & 0.00301 & 0.00301 & 0.00299 \\
\hline Magnesium & 0.00461 & 0.00441 & 0.00431 & 0.00431 & 0.00421 & 0.00419 \\
\hline Aluminum & 0.03624 & 0.04168 & 0.04438 & 0.04709 & 0.04979 & 0.05235 \\
\hline Silicon & 0.24539 & 0.25458 & 0.25909 & 0.26360 & 0.26811 & 0.27144 \\
\hline Sulphur & 0.00300 & 0.00240 & 0.00230 & 0.00180 & 0.00150 & 0.00120 \\
\hline Potassium & 0.01312 & 0.01323 & 0.01333 & 0.01333 & 0.01343 & 0.01356 \\
\hline Calcium & 0.08771 & 0.07284 & 0.06542 & 0.05811 & 0.05060 & 0.04747 \\
\hline Titanium & 0.00170 & 0.00260 & 0.00311 & 0.00361 & 0.00401 & 0.00449 \\
\hline Iron & 0.04155 & 0.04188 & 0.04198 & 0.04218 & 0.04248 & 0.04238 \\
\hline Copper & 0.01081 & 0.01052 & 0.01042 & 0.01042 & 0.01032 & 0.01017 \\
\hline Zinc & 0.00671 & 0.00661 & 0.00651 & 0.00651 & 0.00651 & 0.00648 \\
\hline
\end{tabular}

and the mass attenuation coefficient of concrete samples was calculated by WinXcom.

Figure 5 shows the variation of total mass attenuation coefficient, $\mu_{\rho}$, with energy for the chosen concretes in the wide energy range of $10 \mathrm{keV}$ to $100 \mathrm{GeV}$. Also the experimental data of mass attenuation coefficient for six concrete specimens at $0.662 \mathrm{MeV}$ has been marked in Figure 5. It is observed that $\mu_{\rho}$ decreases sharply in the low energy region, then it becomes almost constant in the medium energy region, and it increases in the high energy region. Figure 5 shows that total mass attenuation coefficients decreased drastically with increasing photon energy in energy region $1 \mathrm{keV}$ to $100 \mathrm{keV}$, it decreased slightly with increasing photon energy in energy region of $100 \mathrm{keV}$ to $10 \mathrm{MeV}$, and it increased slowly and further becomes constant with increasing photon energy in energy region of $10 \mathrm{MeV}$ to $100 \mathrm{GeV}$. This behaviour of $\mu_{\rho}$ confirms the $Z$-dependence of different interaction processes in different energy regions and hence the variation of corresponding mass attenuation coefficients with energy. The results of mass attenuation coefficients confirmed that there is no effect on these radiation parameters (Table 5) with change in flyash content from $0 \%$ to $60 \%$ in place of cement.

\section{Conclusions}

From the undertaken study, the following conclusions can be drawn.

(1) There is well defined decrease in compressive strength results with an increase in cement content by flyash, but still the compressive strength results of flyash concretes were satisfactory and they can be used for construction purposes.

(2) The gain in compressive strength of flyash concretes after 28 days is more than in the case of ordinary concrete. With the increase in age of concrete, strength 


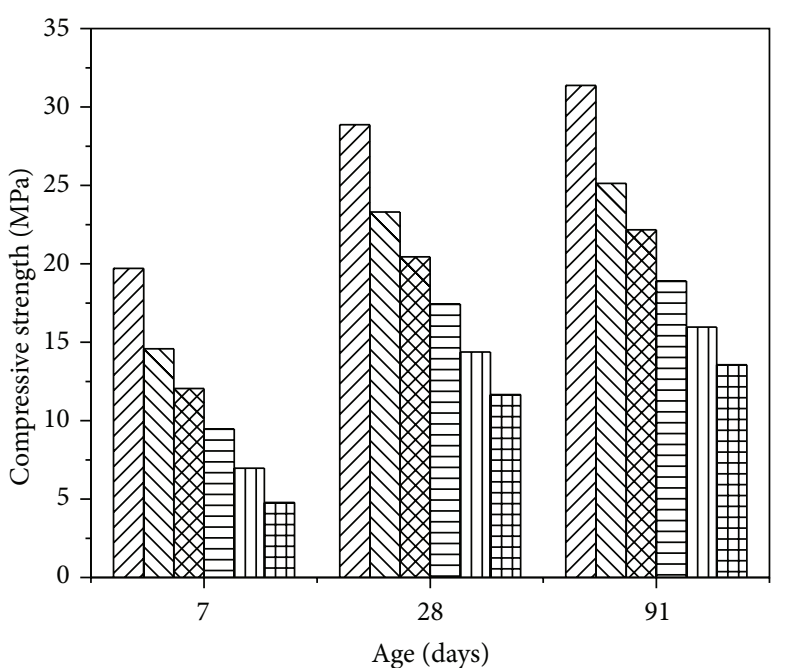

VID Mixture-OC1 (0\% flyash) TIV Mixture-OC2 (20\% flyash) Mixture-OC3 (30\% flyash) Mixture-OC4 (40\% flyash) 血 Mixture-OC5 (50\% flyash) 典曲 Mixture-OC6 (60\% flyash)

FIGURE 2: Compressive strength versus age.

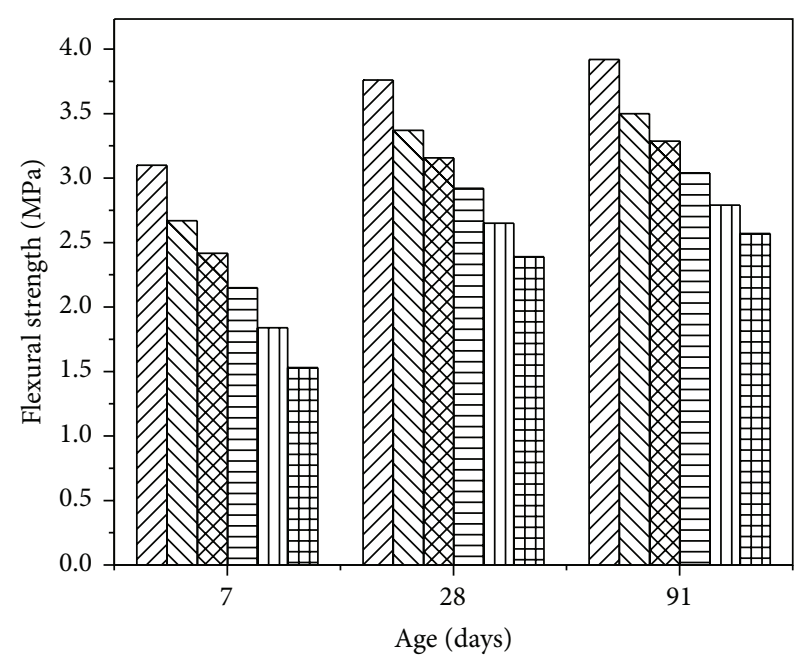

VII Mixture-OC1 (0\% flyash) MIV Mixture-OC2 (20\% flyash) Mixture-OC3 (30\% flyash) 盂 Mixture-OC5 (50\% flyash)

Eixture-OC4 (40\% flyash) 典曲 Mixture-OC6 (60\% flyash)

FIgURE 3: Flexural strength versus age.

TABLE 5: Results of radiation parameters.

\begin{tabular}{lccc}
\hline Sample & $\begin{array}{c}\mu_{\rho} \\
\left(\mathrm{cm}^{2} / \mathrm{gm}\right)\end{array}$ & $\begin{array}{c}\rho \\
\left(\mathrm{gm} / \mathrm{cm}^{3}\right)\end{array}$ & $\begin{array}{c}\mu \\
\left(\mathrm{cm}^{-1}\right)\end{array}$ \\
\hline OC1 & 0.0769 & 2.28 & 0.175 \\
OC2 & 0.0769 & 2.19 & 0.168 \\
OC3 & 0.0769 & 2.14 & 0.164 \\
OC4 & 0.0769 & 2.11 & 0.162 \\
OC5 & 0.0769 & 2.08 & 0.159 \\
OC6 & 0.0769 & 2.06 & 0.158 \\
\hline
\end{tabular}

goes on increasing for flyash concretes. The pozzolanic reaction of flyash develops later than cement.

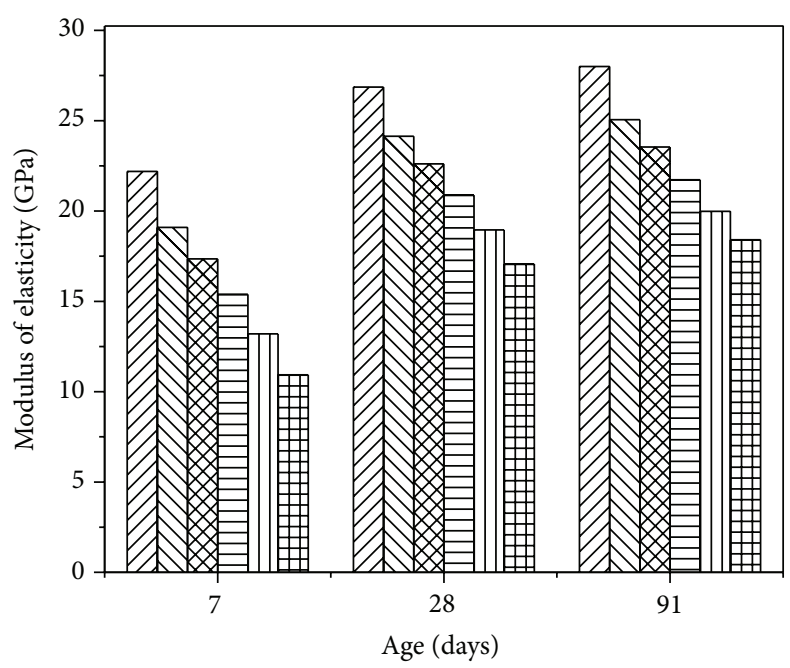

VIn Mixture-OC1 (0\% flyash) IIV Mixture-OC2 (20\% flyash) Mixture-OC3 (30\% flyash) Mixture-OC4 (40\% flyash)

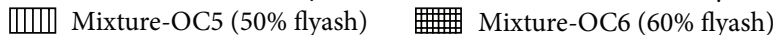

FIgURE 4: Modulus of elasticity versus age.

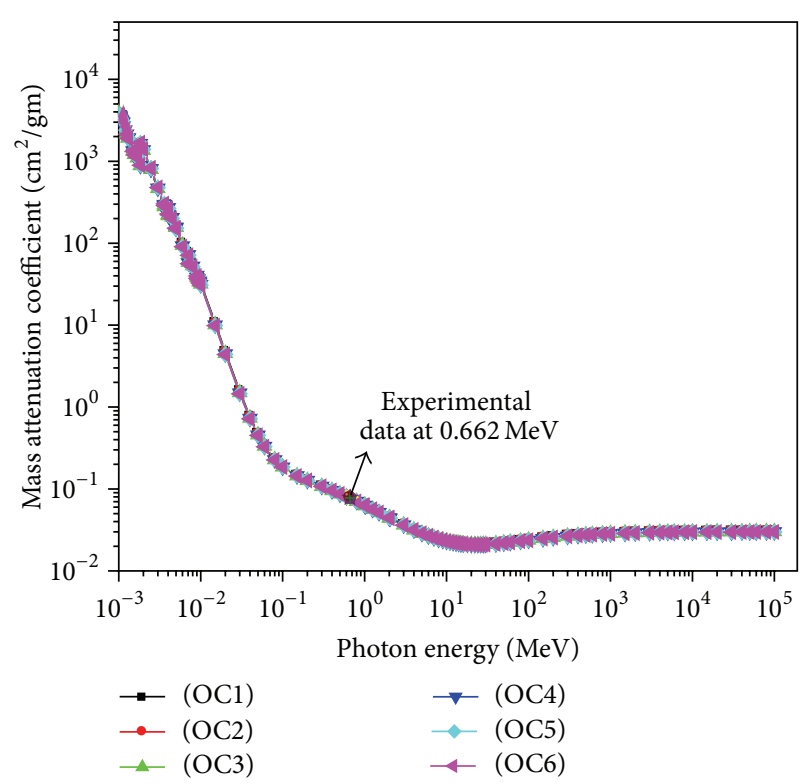

Figure 5: Mass attenuation coefficient with photon energy.

(3) Tensile strength as well as modulus of elasticity of concretes decreases with an increase in flyash content. Decrease is quite less pronounced for the results of tensile strength than in case of modulus of elasticity.

(4) From results it is clear that, with change in flyash content, there is no change in mass attenuation coefficient of all the test specimens with electron density remaining constant.

(5) There is only slight variation in results of linear attenuation coefficient. The linear attenuation coefficient changes with flyash replacement as it is dependent on the density of mixtures. 


\section{Conflict of Interests}

The authors declare that there is no conflict of interests regarding the publication of this paper.

\section{References}

[1] P. K. Mehta and P. J. M. Monteiro, Concrete: Microstructure, Properties and Materials, McGraw-Hill, New York, NY, USA, 3rd edition, 2006.

[2] K. Kovler and N. Roussel, "Properties of fresh and hardened concrete," Cement and Concrete Research, vol. 41, no. 7, pp. 775792, 2011.

[3] A. A. Almusallam, "Effect of environmental conditions on the properties of fresh and hardened concrete," Cement and Concrete Composites, vol. 23, no. 4-5, pp. 353-361, 2001.

[4] A. García, D. Castro-Fresno, and J. A. Polanco, "Evolution of penetration resistance in fresh concrete," Cement and Concrete Research, vol. 38, no. 5, pp. 649-659, 2008.

[5] F. D. Lydon, "Observations on the density and quality of concrete," International Journal of Cement Composites and Lightweight Concrete, vol. 9, no. 4, pp. 205-216, 1987.

[6] M. Kaszyńska, "Early age properties of high-strength/highperformance concrete," Cement and Concrete Composites, vol. 24, no. 2, pp. 253-261, 2002.

[7] J. Li and Y. Yao, "A study on creep and drying shrinkage of high performance concrete," Cement and Concrete Research, vol. 31, no. 8, pp. 1203-1206, 2001.

[8] D. R. Gardner, R. J. Lark, and B. Barr, "Effect of conditioning temperature on the strength and permeability of normal- and high-strength concrete," Cement and Concrete Research, vol. 35, no. 7, pp. 1400-1406, 2005.

[9] S. Zhutovsky and K. Kovler, "Effect of internal curing on durability-related properties of high performance concrete," Cement and Concrete Research, vol. 42, no. 1, pp. 20-26, 2012.

[10] J. Ortiz, A. Aguado, L. Agulló, and T. García, "Influence of environmental temperatures on the concrete compressive strength: simulation of hot and cold weather conditions," Cement and Concrete Research, vol. 35, no. 10, pp. 1970-1979, 2005.

[11] P. G. Bocca and P. Antonaci, "Experimental study for the evaluation of creep in concrete through thermal measurements," Cement and Concrete Research, vol. 35, no. 9, pp. 1776-1783, 2005.

[12] M. Şahmaran, I. Ö. Yaman, and M. Tokyay, "Transport and mechanical properties of self consolidating concrete with high volume fly ash," Cement and Concrete Composites, vol. 31, no. 2, pp. 99-106, 2009.

[13] L. Hong, X. Gu, and F. Lin, "Influence of aggregate surface roughness on mechanical properties of interface and concrete," Construction and Building Materials, vol. 65, pp. 338-349, 2014.

[14] C. Jiang, K. Fan, F. Wu, and D. Chen, "Experimental study on the mechanical properties and microstructure of chopped basalt fibre reinforced concrete," Materials and Design, vol. 58, pp. 187193, 2014.

[15] S. C. Kou and C. S. Poon, "Long-term mechanical and durability properties of recycled aggregate concrete prepared with the incorporation of fly ash," Cement and Concrete Composites, vol. 37, no. 1, pp. 12-19, 2013.

[16] N. Bouzoubaâ, M. H. Zhang, and V. M. Malhotra, "Mechanical properties and durability of concrete made with high-volume fly ash blended cements using a coarse fly ash," Cement and Concrete Research, vol. 31, no. 10, pp. 1393-1402, 2001.
[17] A. R. Boa and L. B. Topu, "Influence of fly ash on corrosion resistance and chloride ion permeability of concrete," Construction and Building Materials, vol. 31, pp. 258-264, 2012.

[18] V. M. Malhotra, "Durability of concrete incorporating highvolume of low-calcium (ASTM Class F) fly ash," Cement and Concrete Composites, vol. 12, no. 4, pp. 271-277, 1990.

[19] L. H. Jiang and V. M. Malhotra, "Reduction in water demand of non-air-entrained concrete incorporating large volumes of fly ash," Cement and Concrete Research, vol. 30, no. 11, pp. 17851789, 2000.

[20] C. S. Poon, L. Lam, and Y. L. Wong, "Study on high strength concrete prepared with large volumes of low calcium fly ash," Cement and Concrete Research, vol. 30, no. 3, pp. 447-455, 2000.

[21] I. M. Nikbin, M. H. A. Beygi, M. T. Kazemi et al., "A comprehensive investigation into the effect of water to cement ratio and powder content on mechanical properties of self-compacting concrete," Construction and Building Materials, vol. 57, pp. 6980, 2014.

[22] N. Bouzoubaâ and M. Lachemi, "Self-compacting concrete incorporating high volumes of class $\mathrm{F}$ fly ash: preliminary results," Cement and Concrete Research, vol. 31, no. 3, pp. 413420, 2001.

[23] R. Siddique, "Performance characteristics of high-volume Class F fly ash concrete," Cement and Concrete Research, vol. 34, no. 3, pp. 487-493, 2004.

[24] C. D. Atiş, "Strength properties of high-volume fly ash roller compacted and workable concrete, and influence of curing condition," Cement and Concrete Research, vol. 35, no. 6, pp. 1112-1121, 2005.

[25] P. Chindaprasirt and U. Rattanasak, "Shrinkage behavior of structural foam lightweight concrete containing glycol compounds and fly ash," Materials and Design, vol. 32, no. 2, pp. 723-727, 2011.

[26] O. Kayali, M. N. Haque, and B. Zhu, "Drying shrinkage of fibrereinforced lightweight aggregate concrete containing fly ash," Cement and Concrete Research, vol. 29, no. 11, pp. 1835-1840, 1999.

[27] M. Gesoglu, T. Özturan, and E. Güneyisi, "Shrinkage cracking of lightweight concrete made with cold-bonded fly ash aggregates," Cement and Concrete Research, vol. 34, no. 7, pp. 11211130, 2004.

[28] I. I. Bashter, "Calculation of radiation attenuation coefficients for shielding concretes," Annals of Nuclear Energy, vol. 24, no. 17, pp. 1389-1401, 1997.

[29] C. Singh, T. Singh, A. Kumar, and G. S. Mudahar, "Energy and chemical composition dependence of mass attenuation coefficients of building materials," Annals of Nuclear Energy, vol. 31, no. 10, pp. 1199-1205, 2004.

[30] B. Oto and A. Gür, "Determination of mass attenuation coefficients of concretes containing ulexite and ulexite concentrator waste," Annals of Nuclear Energy, vol. 59, pp. 72-74, 2013.

[31] J. M. Sharaf and M. S. Hamideen, "Photon attenuation coefficients and shielding effects of Jordanian building materials," Annals of Nuclear Energy, vol. 62, pp. 50-56, 2013.

[32] B. Oto, A. Gür, M. R. Kaçal, B. Doğan, and A. Arasoglu, "Photon attenuation properties of some concretes containing barite and colemanite in different rates," Annals of Nuclear Energy, vol. 51, pp. 120-124, 2013.

[33] A. Un and F. Demir, "Determination of mass attenuation coefficients, effective atomic numbers and effective electron numbers for heavy-weight and normal-weight concretes," Applied Radiation and Isotopes, vol. 80, pp. 73-77, 2013. 
[34] K. Singh, C. Singh, G. S. Sidhu, J. Singh, P. S. Singh, and G. S. Mudahar, "Flyash: a radiation shielding material," Indian Journal of Physics, vol. 77A, pp. 41-45, 2003.

[35] L. Gerward, N. Guilbert, K. B. Jensen, and H. Levring, "WinXCom-a program for calculating X-ray attenuation coefficients," Radiation Physics and Chemistry, vol. 71, no. 3-4, pp. 653-654, 2004.

[36] Bureau of Indian Standards, Indian Standard Code of PracticeMethods of Test for Strength of Concrete, IS:516-1959, Bureau of Indian Standards, New Delhi, India, 1959.

[37] M. L. Gambhir, Concrete Technology, Theory and Practice, McGraw-Hill, 4th edition, 2011.

[38] IS: 516-1959, Indian Standard Code of Practice-Methods of Test for Strength of Concrete, Bureau of Indian Standards, New Delhi, India.

[39] D. A. Abrams, Design of Concrete Mixtures, Lewis Institute, 1919. 


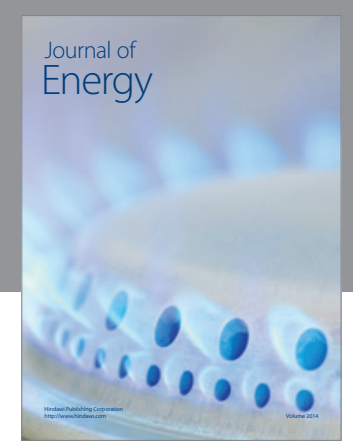

Journal of

Industrial Engineering
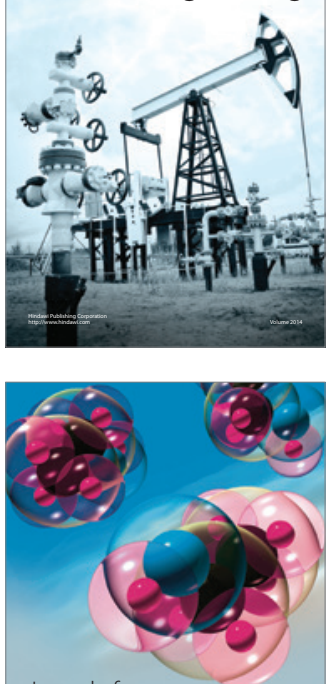

Fuels
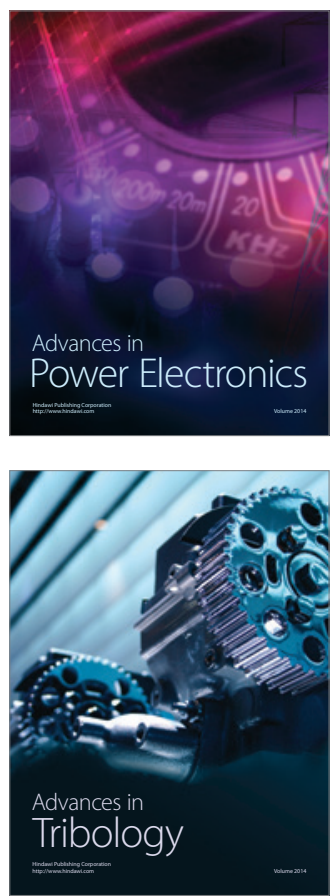

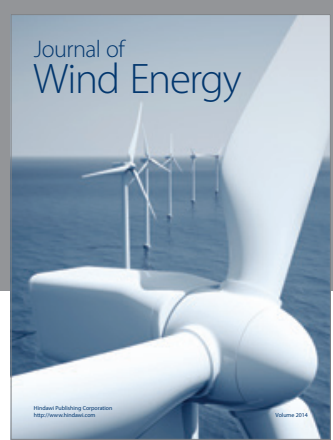

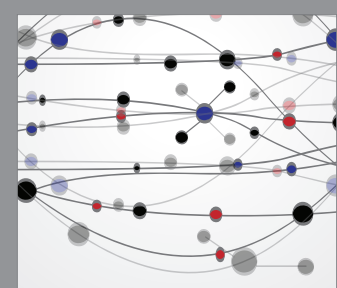

The Scientific World Journal

Submit your manuscripts at http://www.hindawi.com

Journal of

Structures
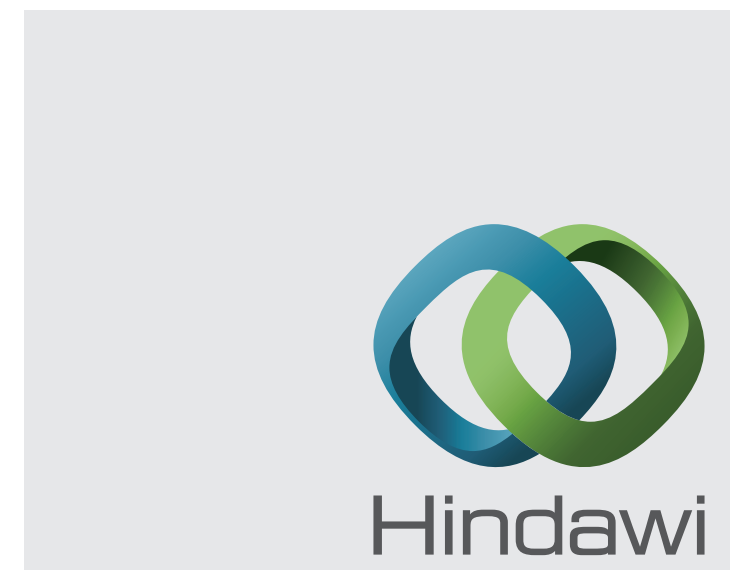

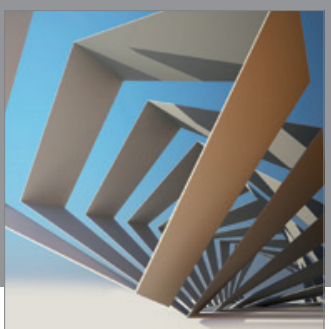

Rotating

Machinery
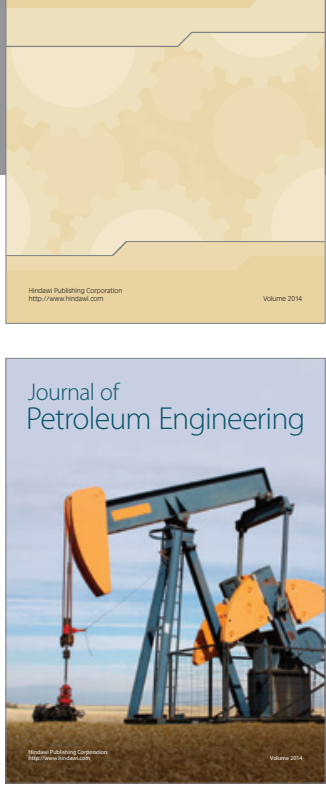

Journal of

Solar Energy
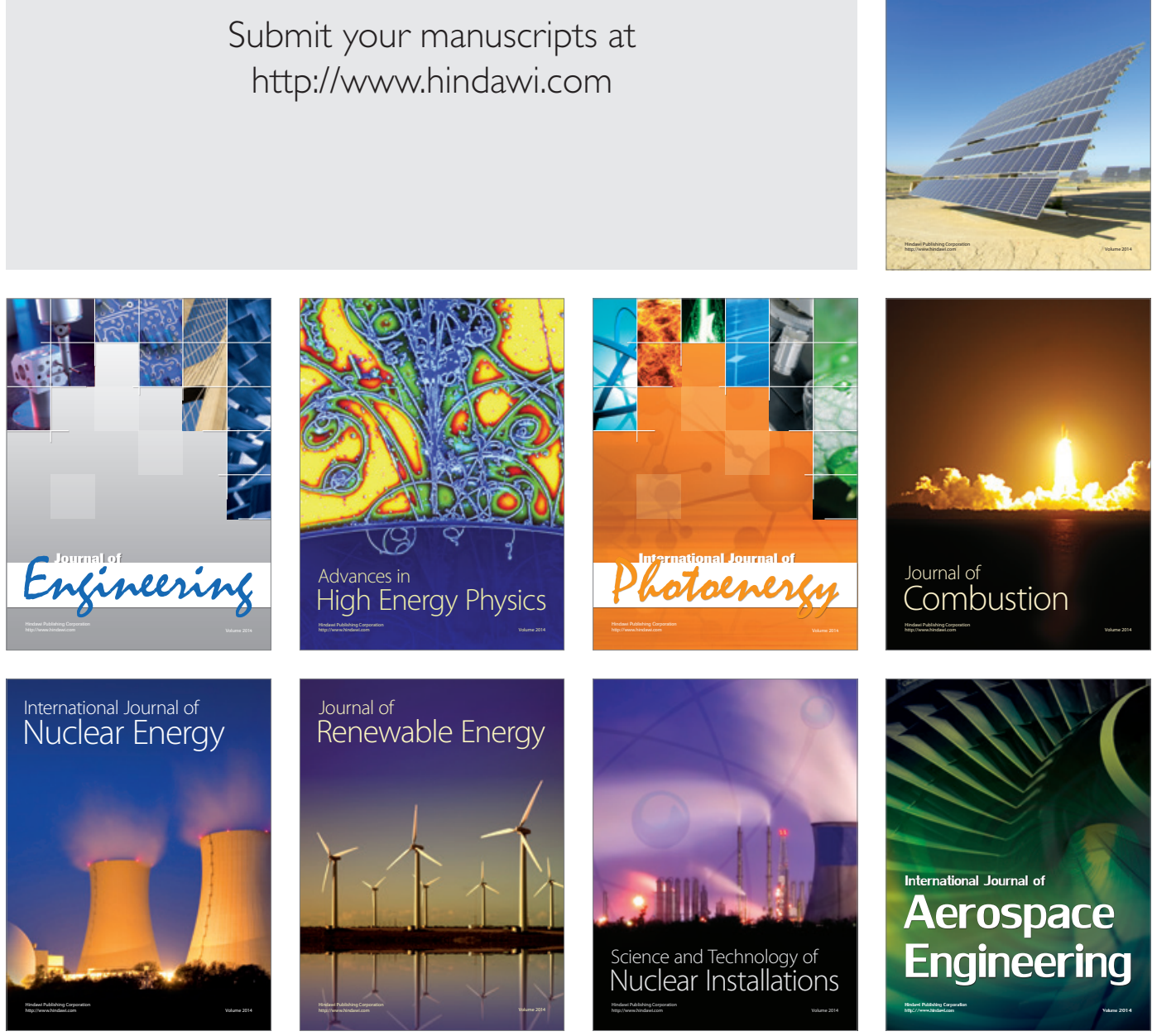